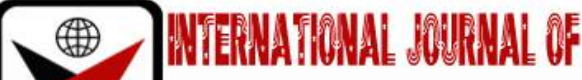

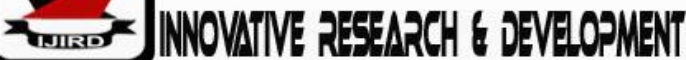

ISSN 2278-0211 (Online)

\section{Global Health and National Interests: The Way Forward}

\author{
Gali Muhammad Kabara \\ Senior Executive Officer, Department of Litigation, \\ Federal High Court, Nigeria
}

\begin{abstract}
:
This paper centers on global health. It shows how communicable disease is a common danger to international community which requires collective efforts in order to make the world a living place. Consequently, the international community adopts International Health Regulations (IHR) to manage the global health. The recent outbreak of the novel Corona Virus (Covid-19), a communicable disease of international concern, gave rise to some serious issues between State Parties to IHR on one hand, and State party and WHO on another. The issues center on allegations of breaching some provisions of IHR to wit: lack of transparency regarding the origin and spread of the virus and mismanagement of information respectively. This made the United States threatening to reconsider its membership in the WHO. The paper considers the issues as capable of threatening international peace and security, it therefore, analyzes some relevant provisions of IHR which shows that the combine effects of Articles 6, 11 \&amp; 45 of the Regulations provide a good legal framework for managing diseases of international concern. However, a political will that gives life to any legal framework which seems to be lacking in this case. The paper also examines the dispute resolution under the IHR which is purely arbitral in nature. Finally, the paper gives some recommendations as a way forward.
\end{abstract}

Keywords: Corona virus, disease, global health, international community, legal framework, politics will, world health organization, international health regulations

\section{Introduction}

The world had seen enough lessons during the Second World War which claimed the lives of the estimated 60 million people between 1939 and 1945. This made the international community to establish a body called United Nations in 1945 for the purpose of maintaining international peace and security by taking effective collective measures to ensure principles of justice, among others. In order to achieve these objectives, the United Nations created some agencies to carry out certain duties. For instance, the United Nations General Assembly passed a resolution on 14th December, 1946 establishing the World Health Organization (WHO) as the official institution within the United Nations system to address the issue of global public health. Some of its principles are: 'the achievement of any State in the promotion and protection of health is of value to all. Unequal development in different countries in the promotion of health and control of disease, especially communicable disease, is a common danger.'

\section{Examinations of Some Relevant Provisions of IHR}

Article $21 \& 22$ of the Constitution of the WHO enable the World Health Assembly to adopt regulations with respect to international health matters, which gave rise to (revised) International Health Regulations (IHR) of 2005.

Article 6 of the Regulations makes it compulsory for each State Party to cooperate in combating diseases of international concern within its territory, thus:

Each State Party shall assess events occurring within its territory by using the decision instrument in Annex 2. Each State Party shall notify WHO, by the most efficient means of communication available, by way of the National IHR Focal Point, and within 24 hours of assessment of public health information, of all events which may constitute a public health emergency of international concern within its territory in accordance with the decision instrument, as well as any health measure implemented in response to those events. If the notification received by WHO involves the competency of the International Atomic Energy Agency (IAEA), WHO shall immediately notify the IAEA.'

Following a notification, a State Party shall continue to communicate to WHO timely, accurate and sufficiently detailed public health information available to it on the notified event, where possible including case definitions, laboratory results, source and type of the risk, number of cases and deaths, conditions affecting the spread of the disease and the health measures employed; and report, when necessary, the difficulties faced and support needed in responding to the potential public health emergency of international concern.'

The above provisions show clearly that it is within the responsibility of each State Party to assess and manage diseases of international concern within its territory. This is not unconnected with the principle of sovereignty of each member of the United Nations. However, in handling the health measures, Article 42 of the Regulations requires the State 
Parties to initiate and complete health measures without delay, and apply them in a transparent and non-discriminatory manner.

Furthermore, Article 11 of the Regulations mandates the WHO to disseminate the received information to all State Parties and intergovernmental organizations as follows:

Subject to paragraph 2 of this Article, WHO shall send to all States Parties and, as appropriate, to relevant intergovernmental organizations, as soon as possible and by the most efficient means available, in confidence, such public health information which it has received under Articles 5 to 10 inclusive and which is necessary to enable States Parties to respond to a public health risk. WHO should communicate information to other States Parties that might help them in preventing the occurrence of similar incidents.'

\section{A Matter of Serious Concern}

The recent outbreak of the deadly Covid-19 in Wuhan, China, a communicable disease which has since taken over the whole world infecting more than five million people and killing more than 300, 000 so far. Earlier on 30th January, 2020 WHO declared the virus outbreak to be a global health emergency, and it later on 11th March, 2020 declared the virus to be a pandemic. However, there having been allegations and counter-allegations with respect to the origin and spread of the virus, and lack of transparency, especially between two great powers: China and the United States, and some other nations on the one hand, and mismanagement of information by the WHO on the other hand.

On 18th May, 2020 the President of the US wrote a letter to the Director-General of the WHO accusing him and the Organization for mismanaging information for the spread of the virus, and further alleged that 'China continues to undermine the IHR by refusing to share accurate and timely data, viral samples and isolates, and by withholding vital information about the virus and its origin.' He further threatened to freeze the US funding to the WHO permanent (which he had earlier made temporary) and reconsider their membership in the Organization if the WHO does not commit to major substantive improvements within the next 30 days.

\section{Dispute Resolution}

The issue at hand indicates a dispute between State Parties on the one hand, and WHO and state party on the other, concerning the application of these Regulations. Article 56 of the Regulations provides for dispute resolution as follows:

- In the event of a dispute between two or more States Parties concerning the interpretation or application of these Regulations, the States Parties concerned shall seek in the first instance to settle the dispute through negotiation or any other peaceful means of their own choice, including good offices, mediation or conciliation. Failure to reach agreement shall not absolve the parties to the dispute from the responsibility of continuing to seek to resolve it.'

- In the event that the dispute is not settled by the means described under paragraph 1 of this Article, the States Parties concerned may agree to refer the dispute to the Director-General, who shall make every effort to settle it.'

- A State Party may at any time declare in writing to the Director-General that it accepts arbitration as compulsory with regard to all disputes concerning the interpretation or application of these Regulations to which it is a party or with regard to a specific dispute in relation to any other State Party accepting the same obligation. The arbitration shall be conducted in accordance with the Permanent Court of Arbitration Optional Rules for Arbitrating Disputes between Two States applicable at the time a request for arbitration is made. The States Parties that have agreed to accept arbitration as compulsory shall accept the arbitral award as binding and final. The Director-General shall inform the Health Assembly regarding such action as appropriate.'

- Nothing in these Regulations shall impair the rights of States Parties under any international agreement to which they may be parties to resort to the dispute settlement mechanisms of other intergovernmental organizations or established under any international agreement.'

- In the event of a dispute between WHO and one or more States Parties concerning the interpretation or application of these Regulations, the matter shall be submitted to the Health Assembly.'

The above suggest that the Regulations contemplates (collective) alternative dispute resolution as the only means for resolving any dispute arising from the application of the Regulations as against unilateral or judicial means. This is apt because the Organization is incapable of enforcing any decision especially against great powers. In fact, the Organization relies majorly on these nations for its sustenance, just like the principal judicial organ of the United Nations.

\section{Observation}

The major problem in the world today is lack of trust among the member states and putting national interests over and above any issue of international concern. National interests become the determining factor for abiding by international responsibilities. Thus, when it comes to United Nations one may be forced to ask how united are the nations? This negates the essence of establishing the international organizations, thereby undermining them from proper management of international issues. The outbreak of the Covid-19 is enough lessons to the international community to be more united than ever before. It is in this sense economist.com reported Bill Gates advising international community that:

'I hope wealthy nations include poorer ones in these preparations, especially by devoting more foreign aid to building up their primary health-care systems. Even the most self-interested person —or isolationist government - should agree with this by now. This pandemic has shown us that viruses don't obey border laws and that we are all connected biologically by a network of microscopic germs, whether we like it or not. If a novel virus appears in a poor country, we want its doctors to have the ability to spot it and contain it as soon as possible.' 


\section{Recommendations}

- Adopting any unilateral measure may only worsen the current situation; rather a collective political solution is necessary.

- It is fair for China to allow an independent investigation as this may alleviate the suspicion and anxiety in the polity.

- Opting out of WHO should not be an option, especially at this critical moment where people are dying in thousands daily.

- There should be sincerity and unity in addressing issues of international concern, such as the current one.

\section{References}

i. Charter of the United Nations and Statue of the International Court of Justice, 1945

ii. Constitution of the World Health Organization, 1946

iii. International Health Regulations, 2005

iv. https://www.economics.com 